\title{
The Influence of Religion Over Family Planning: the Case of the Republic of Macedonia
}

\author{
Kimo Chavdar, Ph.D Associate Professor \\ School of Law, University American College Skopje \\ Marina Andeva, Ph.D Assistant Professor \\ School of Political Science, University American College Skopje
}

Karolina Kedeva, MA, PhD. Candidate

Charles III University of Madrid

Doi: 10.19044/esj.2017.v13n35p112 URL:http://dx.doi.org/10.19044/esj.2017.v13n35p112

\begin{abstract}
Religions have been dominant for thousands of years in each and every aspect of human life, particularly in the domain of the family communion. The influence of religion as a specific form of collective consciousness, and as a system of moral rights and norms, since their appearance until today, is particularly interesting for the Republic of Macedonia. In this small territory, despite the fact that a variety of different religious communities have coexisted throughout the centuries, yet there is a major difference in the approach of family planning customs. This is mostly evidenced in the cases of the population representing the Orthodox Christian and Muslim religions. In this article we elaborate, firstly the viewpoints on family planning and reproduction of the Orthodox Christian and Muslim religions as the dominant religions in the Republic of Macedonia and discuss viewpoints and attitudes towards family planning (abortion) among the Macedonian citizens.
\end{abstract}

Keywords: Family planning, Republic of Macedonia, Islam, orthodox, religion

\section{Introduction}

Religion represents acceptance of certain statements to be true, by one's free will. From a man's perspective religion would be acceptance of a father's claim to be a father, of a mother's claim to be a mother, and mutual acceptance of two spouses to live together freely, selflessly, in a unity of peace love and togetherness (Perić, 2011).

In that respect religions have been dominant for thousands of years in each and every aspect of human life, particularly in the domain of the family 
communion. The religious norms have been considered the primary social and political means in charge of regulating family and marital life. Religions had a very strong impact on all significant events in human life: birth, conclusion of marriage, death.

Most religions have adherence to human reproduction and birth control in one way or another. Generally speaking, most of the religions were supporting the pro-birth approach, with a tendency towards promoting higher birth rate, which can be evidenced in written texts, as remaining proof of oral evidence, despite the current modern approaches on this issue.

The influence of religion as a specific form of collective consciousness, and as a system of moral rights, norms, guidelines, orders and laws since their appearance until today, is particularly interesting for the territory of the Republic of Macedonia. In this small territory, despite the fact that a variety of different religious communities have coexisted throughout the centuries, yet there is a major difference in the approach of family planning customs. This is mostly evidenced in the cases of the population representing the Orthodox Christian and Muslim religions in the Republic of Macedonia (Stojmilov, 2000).

It is an inevitable fact however that in recent years, together with the contemporary socio economic circumstances, the reproductive behaviors and habits of society has shifted, thus in turn making even the most Orthodox Christians abandon the theological rules of conduct in many aspects of their lives. The modern way of life, the focus towards materialistic interests, gathered with the recent world views, and altered life practices, largely modified the religious dogma. Thus the religious and moral, requirements, and rules of behavior, regardless of their depth of embedment in the soul of the most robust and conservative believer, whether belonging to the Orthodox Christian, Muslim or any other confessional community, become susceptible to his/her personal interests, and common problems in nowadays society, leading to changes in the spiritual life of man and leaving the religious rules and values sooner or later to be abandoned permanently.

In this paper we will elaborate, firstly the viewpoints of the Orthodox Christian and Muslim religions as the dominant religions in the Republic of Macedonia and will present secondary findings on the attitudes towards family planning (abortion) among the Macedonian citizens.

\section{Child birth and family planning according to the Orthodox Church}

The Eastern Orthodox Church is based upon the canons of the Scripture, and is thus in turn against terminating pregnancy, contraception, disparaging equally abortion and contraception. According to the Holy Bible, life is the most precious gift; it is the prerogative of God. In the Old Testament, since the Moses laws, abortion as a result of negligence is 
forbidden. However, there is no direct ban on deliberate abortion. In the New Testament and its Gospels, nothing is said in this regards, so the standpoints from the Old Testament are to be accepted without exception on this topic.

In its moral teachings, the Orthodox Church has had a long history of outspoken condemnation of abortion which dates back to Apostolic times. In fact the humanity of the unborn child and its possession of a soul from the moment of conception has been almost universally understood in the Eastern Church from the earliest times and is firmly grounded in Scripture. The oldest Christian document of authority that condemns abortion is the "Didache" or "The Teaching of the Twelve Apostles", a document of the primitive Church dating back to at least the late First Century. Other similar condemnations of the practice are found in Canon 63 of the Council of Elvira (306AD); Cannon 21 of the Council of Ankara (314AD). However, it is in Cannon 91 of the Quinsext Ecumenical Council (Trullo, 692AD) that the Church's teaching on abortion took its final expression and was formally codified in the document The Photian Collection in 883AD, which remains unaltered to this day. As clearly delineated in the canons, the Orthodox Church considers abortion as premeditated murder, and considers the abortionist, the one who carries out abortion, and the woman who terminates her pregnancy as murderers. (Orthodox Christians for life, 2002).

The position of the church today, and according to the interviews carried out in the Faculty of Theology in Skopje, regarding abortion is clear and stems from the ten Commandments and in particular the commandment "do not kill". The impact of the said order is universal and absolute, although concerns a single murder carried out by a single man. Nonetheless it is important to note that obeying the commandment not to kill does not only regard the physical but also encompasses avoiding murderous motive and intent. Because of this fact, this commandment from the aspect of the Orthodox Church perspective is considered very layered, covered with the veil of secrecy, ethically fruitful, and ontological secretive (Grozdić, Gostović \& Kajtez, 2013).

This stems from the history of the development of the Orthodox Church where the rules (canons) of the Trullo summit (Ekonomou, 2007) which was held in Constantinople from 07.11.680 to 16.09.681, as well as from the other seven Universal summits held in Constantinople in the period until 787 year, demonstrate how rules should be strictly observed, and thus unequivocally equal the participants in execution of the abortion with murderers, including both the woman who is being released from the fruit, and the person by which the abortion is committed. Nonetheless, contraception has been also equalized with murder according to the teachings of the Orthodox Church, derived from the texts in the Old Testament. 
Since the Orthodox Church reads the text of the Bible in its exact terms, we would like to mention certain thoughts regarding the birth of children. In particular orders and recommendations, given by Moses and certain prophets to the people of Israel, elements of demographic policy can be sensed, which suggest to the people at that time that by increasing or decreasing birth rate, certain goals can be achieved. So in Genesis (1.Moses. 22.17) it is said "That in blessing I will bless thee, and in multiplying I will multiply thy seed as the stars of the heavens, and as the sand which is upon the seashore; and thy seed shall possess the gate of his enemies." Furthermore, according to Genesis 1.28, when God created man and woman, he blessed them with the words "Be fruitful and increase in number; fill the earth and subdue it. Rule over the fish in the sea and the birds in the sky and over every living creature that moves on the ground." (Genesis 1:28). Nonetheless not only is the number important but the very act of birth is described as an incredibly bright act. Thus in Revelations 12, 1-2 the following is described: "A great sign appeared in heaven: a woman clothed with the sun, with the moon under her feet and a crown of twelve stars on her head. She was pregnant and cried out in pain as she was about to give birth." In these texts the women in labor are upon all known as lasting light sources, light is born, a new being will receive sight, the world will receive light.

Regarding infertility, it was seen as a punishment by God, and having no children in marriage had its own meaning, connected with the will of God. However, there is estimation that the Orthodox Church is more flexible than the publicly declared opinions on this issue and that it traditionally puts the responsibility of both spouses on first place when making decisions according to their consent regarding the birth of children.

\section{Child birth and family planning according to the Muslim religion}

What is distinctive about the Muslim religion is that family planning is considered as a private measure to determine the time of birth and consequently regulating family size for health or economic reasons. Neither in the Qur'an nor in the hadith there are passages that are against birth control. The Muslim religion does not forbid abortion, nor limits childbirth (Jovanovic, 1998). This conclusion derives from several hadiths which are categorical when stating that family planning i.e. birth planning is allowed (Nahj al-Balāgha, saying 141; Surah al-Araf, Verse 172; Wasāil ash-Shī a, vol. 14, pg. 105).

The Muslim religion expresses learning that enables polygamy. According to the Qur'an sexual life of man is quite pronounced. Islam, especially emphasizes giving dowry to the woman in marriage, and for inheritance women exercise certain rights, but not to that extent as those of men. It is thought that a polygamous marriage, for the members of this 
religion and women from other religion, have fewer offspring of the marriage, taking into account the number of births of children per woman. Therefore, it is believed that polygamous marriage is an indirect tendency of reduction of population growth.

Nevertheless, the influence of the Muslim religion was aimed at increasing population. Muhammad as prophet said: "Marry, because with your help I want to surpass other nations". In this religion, sexual restraint and ascetic attitude toward life, are not the case, except when a woman has menstruation and 40 days before and after delivery and before any major holidays. In the Qur'an wife is censured for Adam's 'first mistake'. Then Islam approves preventing conception of the individual, for good cause, and prohibit the community as a whole.

The prevention of conception sometimes is forbidden, if spouses are sick, if they suffer certain illness, which will be inherited to their offspring, or in the case of a general mobilization to defend the country from the enemy. If Muslim women find themselves in combat, they are obliged to prevent conception, because otherwise it could not carry out their duty to defend the homeland. Also the prevention of conception is desirable if spouses are serving prison times, primarily because of the child who will be born under such conditions, will not be able to have the adequate comfort that is needed for education and development. Contraception is allowed if the woman is weak and sick, and if the man is too poor and unable to work. But for prevention of conception permission and consent of both spouses is necessary, with special emphasis on the voluntary consent of the woman. For these reasons, for some Islamic scholars, prevention of conception is considered as an act of praise.

Also in the Qur'an it is written "Do not kill your children for fear of poverty, we will take care of them" (Süratal-An ām, Verse 151), stating that the Islam has a positive attitude towards procreation. The Qur'an and Hadith have quite present issues of marriage and family life, but no pronounced position on birth control and according to the teachings of Muhammad coitus interruptus is permitted, therefore it can be concluded that using contraceptive for preventing pregnancy is allowed (Wasāil ash-Sh̄̄ a, vol. 14, pg. 105 and 106) (Sharh Lum'a, vol. 2, p. 28; al-'Urwah, p. 628; Minhaj, vol. 2, p. 267).

Sharia laywer Sejfulah - efendija Proha states that woman can interrupt pregnancy with the permission of her husband and miscarriage is allowed before the fourth month of pregnancy (it is considered that after the fourth month of pregnancy the soul enters in the fetus), and after the fourth month only in exceptional cases. An abortion after the fourth month is considered an attack of murder of the innocent child and a major crime, and pulls each conviction. According to Imam Ghazali: "To destroy the fused 
female and male sperm into the uterus ready to accept life is transgression and a sin. For infants in the Qur'an Allah says: "Property and sons are ornaments of worldly life". In that sense the killing of living children is a great sin. The killing of innocents and is evidence of a lack of awareness and compassion a sign of desolate and empty heart of mercy and love. If you kill a child in the womb, fearing poverty, it is a double sin, because it is about murder and despair - losing hope and mercy of Allah (Ljevakovic, 1999). According to the Qur'an, abortion is prohibited because it often causes inflammation of the uterus, closing fertility organs and finally concluding with permanent infertility. Many women succumb, so the danger of abortion is clear and the prevention of conception and repulsively ugly (Hasanović, 1997)

Looking historically, Islamic religion, depending on the circumstances and needs, had different views. In 1838 a Royal screed treated miscarriage as murder and stated that it would punish any offense, and doctors and pharmacists need to swear that they will no longer perform miscarriages in front of religious authorities. This screed was current at that time due to the large number of wars and pestilence that ruled, so the population dropped (Jovanovic, 1998). Thus, the Islamic Religious Community in Macedonia opposes the believers who use contraception or intentional miscarriage, but provided that it is by mutual consent of the spouses. On a practical level however, such decisions are best made with mutual consultation between the husband and the wife; otherwise, it could lead to misunderstanding and mistrust. The legal aspect is to protect the basic rights of women, but in the real world, man and woman must base their life on love, mercy and cooperation as it is stated in Surat al-Rūm (30), Verse 21: "And He ordained affection and mercy between you."

\section{Family planning and religious affiliation in Republic of Macedonia}

In order to depict, by comparing, how religious affiliation reflects population growth and family planning in Republic of Macedonia, statistical data will be shown in this section of the paper. The available official statistical data (until 2002, when the last population census was performed in Macedonia) will present the family planning in the country through the analysis of birth rates and participation in the population growth by religious affiliation.

The structure of the population in Republic of Macedonia is characterized by presence of many religious communities. Namely, in Macedonia there are two primary religious groups. The Orthodox is represented by Macedonians, Serbs, Vlachs and others, encompassing the majority of the population, and Islamic, which is mainly consisted of the Albanians, Turks and Macedonians of Islamic faith. According to the census 
of 2002 from the total population, 1,310,184 people or $64,8 \%$ are Orthodox Christians. The Muslim population accounts for 33,3\% or 674,015 people. The Catholics are present with or $0,3 \%$ of the total population or 7008 persons. There are 520 people or just $0,026 \%$ of the total population declared as Protestants; and the other smaller religious communities account for a total of 30,820 people (see Table 1 ).

With the continued growth of the population, changes occurred in the percentage of the population which can be seen here by ethnicity and religion. For example, in 1953 the percentage of Macedonians, dominant representatives of the Orthodox religion, in relation to the total population amounted to $66 \%$, in $1971,69.3 \%$, in $1994,66.6 \%$ and $64.18 \%$ in 2002 , while in 1953 the percentage of Albanians, as the dominant ethnicity of the Muslim religious affiliation, in the total population amounted to $12.4 \%$ in $1971,17 \%$, in $1994,22.7 \%$, and $25.17 \%$ in 2002 The increase of the Albanian population from $12.4 \%$ in 1953 to $25.17 \%$ in 2002 is evident.

Here we would like to mention that in the 1994 census, there is no official data in terms of religious affiliation, but only on ethnicity. In that sense, the data presented here are projection of the percentage of Macedonians as the largest Christian orthodox community in the country and Albanians as the largest Muslim community in the country. In fact, for almost five decades the participation of this ethnicity in percentages, as a Muslim group, nearly doubled, which completely changed the demographic picture of the country. According to the confessional structure, the population expressed themselves as Christian orthodox in 1994 is $67.8 \%$ of the total population, and in 2002 is $64.8 \%$, while the Muslim population in 1994 is $30 \%$ of the total population, and in 2002 is $33.3 \%$ (Talevski \& Temjanovski, 2003).

Based on comparative data (see Table 2) for the two most prevalent religions in Macedonia it is shown that the share of Muslim population is increasing, and the population with Orthodox Christian is decreasing. It can be concluded that Islamic population in Macedonia has a higher birth rate. As reasons for stating the circumstances that Islam through its religious teaching directly influences people's behavior in everyday life, especially in reproductive behavior. Islam tends more to this world to provide governance and application of God's law because it relates to all aspects of life. In this sense the problem of birth is treated with the relationship of the necessity of the event, depending on God's giving and the freedom of the individual under this provision to decide according to own consciousness. Islam is more practice than doctrine, and therefore it is important for adherence to religious and social practices that are rooted in the lives of Muslims.

The questions of having many children is mostly present in the Islamic tradition, where the woman is subordinate to man by God's will and 
on judgment day she will first address her prayers, and then the obedience to men. It is a religious duty to have the marriage fruitful (to produce more children as fruits), because it is a pride to have many children. Mothers with many children deserve respect and worship, i.e. women achieve their family and social values only through motherhood. As available data shows (in Table 3) the presence of more than three children is characterized mostly in the Muslim population.

In Figure 1 we can clearly notice that the data on the share in the population growth by religious affiliation reveals that through the years, the Muslim community in the country has played a significant role in the overall population growth.

Observing the overall statistical data from the last 25 years in the country, the natural population increase was continuously positive, but with a reduced pace. The rate of natural increase (which shows the natural increase per 1000 inhabitants) declined from 8.1 persons per 1000 inhabitants in 1994 to 1.3 persons in 2015. The birth rate from 1994 to 2015 (the number of live births in 1000 inhabitants) is decreasing from 16.1 in 1994 to 11.1 in 2015 (State Statistical Office of the Republic of Macedonia, 2016: 6).

\section{State policies and citizens' attitudes towards family planning in Republic of Macedonia}

When discussing population growth and family planning, a considerable attention should be made also to the state policies and citizens statements and attitudes towards these issues. Every state should guarantee conditions for family planning and for free and responsible partnering. This is guaranteed by the art. 5 of the Family Law. The same law also gives equal parenting rights to both parents (art. 45). It is without a doubt that parents are independent in the decision of having children, as well as their number. What we have seen in this paper is the influence of religion in this specific issue. Religion plays a major role, however also other factors influence family planning, such as economic and social conditions, and state policies and laws on abortion.

Abortion or termination of unwanted pregnancy is one of the most controversial issues in the world, that constantly causes fierce public debate. Until recently, in Macedonia the public debate on abortion was never fought with such great interest as is the case in other countries of the world, nor there were diametrically opposed views, possibly because since 1972 in the country there are fairly liberal laws on termination of pregnancy, in which the woman is guaranteed the right to decide on her pregnancy and the right to free access to abortion. However, recent changes in legislation on abortion that were passed (art. 6 of the Law on termination of pregnancy, 2013), indeed caused an avalanche of violent reaction in the media and in public. In 
fact, these amendments to the law make writing an application for termination of unwanted pregnancy by the woman to the health facility compulsory, followed by mandatory counseling about the possible advantages of continuing the pregnancy and the risks to women's health from the implementation or non-implementation of abortion. Finally, there are also three days of waiting after the consultation to make medical intervention of termination of pregnancy. According to the reactions of experts and nongovernmental organizations, the amendments limit the right of free choice for women and further complicate and bureaucratize the process of obtaining health service abortion.

The changes in legislation were preceded by intensive media campaign entitled "Choose life, you have a choice." For this campaign, the Government of the Republic Macedonia in 2009 opened a public call for recording promotional TV spots explaining the consequences and risks of abortion. Anti-abortion campaign begins to broadcast most intensive at the beginning of 2011 and comprised a total of six promotional videos entitled Youth, Arguments, Parent, Fetus, Beethoven and Wealth that is still shown on television screens. Such campaign caused many reactions in the waste public, which resulted in a research performed by one prominent nongovernmental organization in the country aimed at mapping the attitude of the citizens pro or con abortion. For better understanding the country profile in this paper, we think it is interesting for the public to be familiarized with this research.

The research supported by the organization H.E.R.A (an association for health education and research) in 2013 reviled that the majority of respondents $(67 \%)$ believe that women should make their own decisions about abortion, and $23 \%$ of respondents disagree with the above statement. Also, a small part of all respondents (7\%) expressed an indefinite attitude towards abortion. Citizens who disagree that women should decide themselves about abortion, often believe that the right should be limited because this decision should be made together with the partner (73\%). As other reasons for limiting the right to abortion is mentioned that women should get permission from their partner (13\%); abortion should not exist because it is a murder (8\%); women should consult their parents $(7 \%)$ or they should consult a doctor $(7 \%)$. The citizens who mostly believe that women should not decide alone for the termination of pregnancy are belonging to the Albanian ethnicity, aged 15-24, from Muslim religion. Table 4 presents only the data which reveal the higher percentages of agreements and disagreements, towards the question whether women should decide alone for abortion. This table shows only high percentage from three types of respondents: age, ethnicity and religious affiliation. 
Condemnation or justification of the woman who terminated pregnancy is also an interesting aspect to be seen and was covered by the above mentioned research. The respondents were asked to answer whether they say a woman who had an abortion made a wrong or right choice. 39\% of all respondents stated that women who had an abortion made a wrong choice, $35 \%$ believe that the woman acted wrongly and the remaining $26 \%$ of respondents either did not know or did not want to answer the question. The respondents who thought that women made a wrong choice are mostly young respondents (aged 15-24 years), female, ethnic Albanians, living in rural, unemployed with primary education, Muslim and with lowest monthly household income (Ugurovska, 2013: 11).

\section{Concluding remarks}

Parenting is a free choice of every person and its realization is possible only by respecting the individuality and the rights that are guaranteed in a modern democratic society. As in many countries in the world, in Macedonia for many women and couples, religious, cultural, gender, and social norms 'dictate' family planning. Family planning as basic human rights, allows couples and individuals to decide by a free choice, the number, spacing and timing of their children. From the many factors which play significant role in parenting and family planning, in this paper, we have elaborated the religion affiliation as the primary one. In the lack of research on family planning in Macedonia, we have tried to contribute in the research community by giving a modest input in this field of study. Family planning is included in religions across the spectrum as a moral good, a responsible choice, and a basic human right. Religions in the world recognize that family planning helps build strong families, protect the health of women and children, reduce child and spousal abuse, and prevent unintended pregnancies. In this paper we have taken into consideration two religions Cristian Orthodox and Islam as dominant religions in the Republic of Macedonia. We have presented the views and attitudes of both religions and depicted data by religious affiliation in Republic of Macedonia in what concerns birth rate and inclusion in the overall population growth in the country.

Although according to the data presented in this paper, we do not consider that religious affiliation is the main, decisive and only determinant of reproductive behavior, but still it is one of the greatly important factors together with the cultural, educational, political, historical, psychological, and economic factors that have quite a say in the formation of procreative plans. Members of the Islamic religion in our country, although belonging to four nationalities, all tend to demonstrate the nearly identical pattern of reproductive behavior (Demirgiev, 1991). 
The results of our research has suggested that yet the religious affiliation, and the intensity of the religious feelings, still have a strong impact on the reproductive behaviors and decision making of the population on the territory of the country.

\section{References:}

1. Demirgiev K, (1991) Avtogenocid [Autogenocide]. Skopje

2. Đurović Z. (1997) Crkveni kanoni [Church canons]. Dam-Komerc: Beograd

3. Ekonomou J. Andrew.(2007) Byzantine Rome and the Greek Popes. Lexington Books

4. Enciklika Papa Pie XI (1931) Kaptola vrh bosanskoga Sarajevo

5. Encyclical letter Humanae vitae of the supreme pontiff PAUL VI Libreria Editrice Vaticana 1968

6. Family law, Official Gazette of the Republic of Macedonia n. 80/1992 (with consequent amendments).

7. Federal Statistical Office (1959). Popis stanovništva 1953 godine. Knjiga I. Vitalna i etnička obeležja. Konačni rezultati za FNRJ $i$ narodne republike [Population census 1953, Book I, Vital and ethnic characteristics. Final results for Federal People's Republic of Yugoslavia and people' republics. Belgrade.

8. Grozdić B.,Gostović. D. Kajtez.I, (2013) O ubistvu u kanonima pravoslavne crkve [On murer and canons of orthodox church]. Defendologija: Banja Luka

9. Hasanović.M, (1997) Pravo nerođene djece na život i kur"an [Right to unborn children in Quran]. Tuzla.

10. Jogan, M. (1987). Religija i planiranje porodice [Religion and family planning]. In Socijalna politika $i$ socijalni rad [Social politics and social work], 23, 5-6, pp. 73-82

11. Jovanovic, A. 1998) Rodnosta $i$ planiraweto na semejstvoto vo Republika Makedonija [Fertility and family planning in Republic of Macedonia]. Metamorfoza: Skopje.

12. Law on termination of pregnancy, Official Gazette of the Republic of Macedonia n. 87 /2013 (with consequent amendements).

13. Ljevakovic, H. (1999) Zenata vo islamot [Woman in Islam]. Islamic community in Republic of Macedonia.

14. Merali, A. \& Merali, S. (--) Chapter 4: Family Planning. In From Marriage to Parenthood The Heavenly Path. The Islamic Education Board of the World Federation of Khoja Shia Ithna-Asheri Muslim Communities, retrieved from https://www.al-islam.org/frommarriage-to-parenthood-heavenly-path-abbas-and-shaheenmerali/chapter-4-family-planning (accessed November 15, 2016). 
15. Orthodox Christians for life (2002). Prolife Handbook: The Basics. The Orthodox Christians for Life: New York

16. Perić, R. Mons.(2011) Znanost i vjera u dijalog [Science and faith in dialogue]. Zbornik radova Suvremena znanost vjera. Mostar.

17. State Statistical Office of the Republic of Macedonia (2016). 25 години независна Македонија [25 Years Independent Macedonia]. Skopje.

18. State Statistical Office of the Republic of Macedonia, retrieved from www.stat.gov.mk, (accessed October 30, 2016).

19. Stojmilov, A. (2000), Veroispovedna struktura na naselenieto vo Republika Makedonija [Confessional sstructure of the population in the Republic of Macedonia]. Geografski razgledi Skopje.

20. Talevski, J. \& Temjanovski, R. (2003) Military-demographical characteristics of ethnical and confessional structure of population in Republic of Macedonia. Skopje.

21. Ugurovska, B. (2013). По четиригодинната кампања: ставови кон абортусот помеѓ општата популација и гинеколозите во Македонија [After 4 years' campaign: attitudes towars abortuion among the general public and gynecologists in Macedonia]. H.E.R.A: Skopje

\section{Tables}

Table 1. Population structure according to religious affiliation in the Republic of Macedonia in 1953, 1994 and 2002, in percentage

\begin{tabular}{cccc}
$\begin{array}{c}\text { Religious } \\
\text { affiliation }\end{array}$ & 1953 & 1994 & 2002 \\
\hline Orthodox & 57,4 & 67,8 & 64,8 \\
Muslim & 29,9 & 30,0 & 33,3 \\
Catholic & 0,35 & 0,4 & 0,3 \\
Protestant & 0,11 & 0.1 & 0.026 \\
Other & 13 & 1,7 & 1,5
\end{tabular}

Source: Data retrieved from the State Statistical Office of the Republic of Macedonia.

Table 2. Live births by religious affiliation of the mother, 1950-2013, in percentage

$\begin{array}{llllllll}\text { Religious } & 1950 & 1960 & 1970 & 1980 & 1990 & 1995 & 2013\end{array}$ affiliation

$\begin{array}{cccccccc}\text { Orthodox } & 62.5 & 57.8 & 55.1 & 56.8 & 52.5 & 49.3 & 50,07 \\ \text { Muslim } & 32.9 & 34,9 & 39,7 & 38,2 & 42,6 & 45,9 & 47,4 \\ \text { Other } & 4.6 & 7.3 & 5.2 & 5.0 & 4.9 & 4.8 & 1,9\end{array}$

Source: Data retrieved from the State Statistical Office of the Republic of Macedonia, and manually elaborated by the authors. 
Table 3. Live births by order of birth and religious affiliation of the mother, 1950 and 1989

$\begin{array}{ccccccc}\begin{array}{c}\text { Order of } \\ \text { birth } \\ \text { Years }\end{array} & \begin{array}{c}\text { First child } \\ \mathbf{1 9 5 0 / 1 9 8 9}\end{array} & \begin{array}{c}\text { Second } \\ \text { child } \\ \text { 1950/1989 }\end{array} & \begin{array}{c}\text { Third } \\ \text { child }\end{array} & \begin{array}{c}\text { Fourth } \\ \text { child }\end{array} & \begin{array}{c}\text { Fifth } \\ \text { child }\end{array} & \begin{array}{c}\text { Sixth } \\ \text { child }\end{array} \\ & & & & & & \\ \text { 1950/1989 } & \mathbf{1 9 5 0 / 1 9 8 9} & \mathbf{1 9 5 0 / 1 9 8 9} \\ \text { Orthodox } & 31,6 / 47,4 & 26,8 / 39,8 & 15,3 / 8,7 & 9,9 / 1,5 & 5,3 / 0,8 & 18,6 / 0,5 \\ \text { Muslim } & 21.6 / 36,3 & 18.1 / 29,6 & 15,2 / 17,6 & 12 / 6,5 & 9,2 / 3,6 & 19,8 / 3,4 \\ \text { Other } & 31.8 / 38,4 & 23.6 / 30,2 & 16.9 / 5,8 & 10.0 / 1,9 & 4.8 / 1,4 & 8.5 / 1,4\end{array}$

Source: Data retrieved from the State Statistical Office of the Republic of Macedonia, and manually elaborated by the authors.

Table 4. Attitudes (measured in percentage of respondents for each statement) towards women decision for abortion.

Age

Women should decide alone for abortion

Women should not decide alone for abortion
Ethnicity Religion

\begin{tabular}{ccc}
$25-44$ years old & Macedonian ethnicity & Orthodox \\
\hline $71 \%$ & $76 \%$ & $75 \%$
\end{tabular}

\begin{tabular}{ccc}
$15-24$ years old & Albanian ethnicity & Muslim \\
\hline $31 \%$ & $45 \%$ & $44 \%$
\end{tabular}

Source: (Ugurovska, 2013: 8)

\section{Figures}

Figure 1. Percentage share in the growth of the population according to religious affiliation by years of population censuses

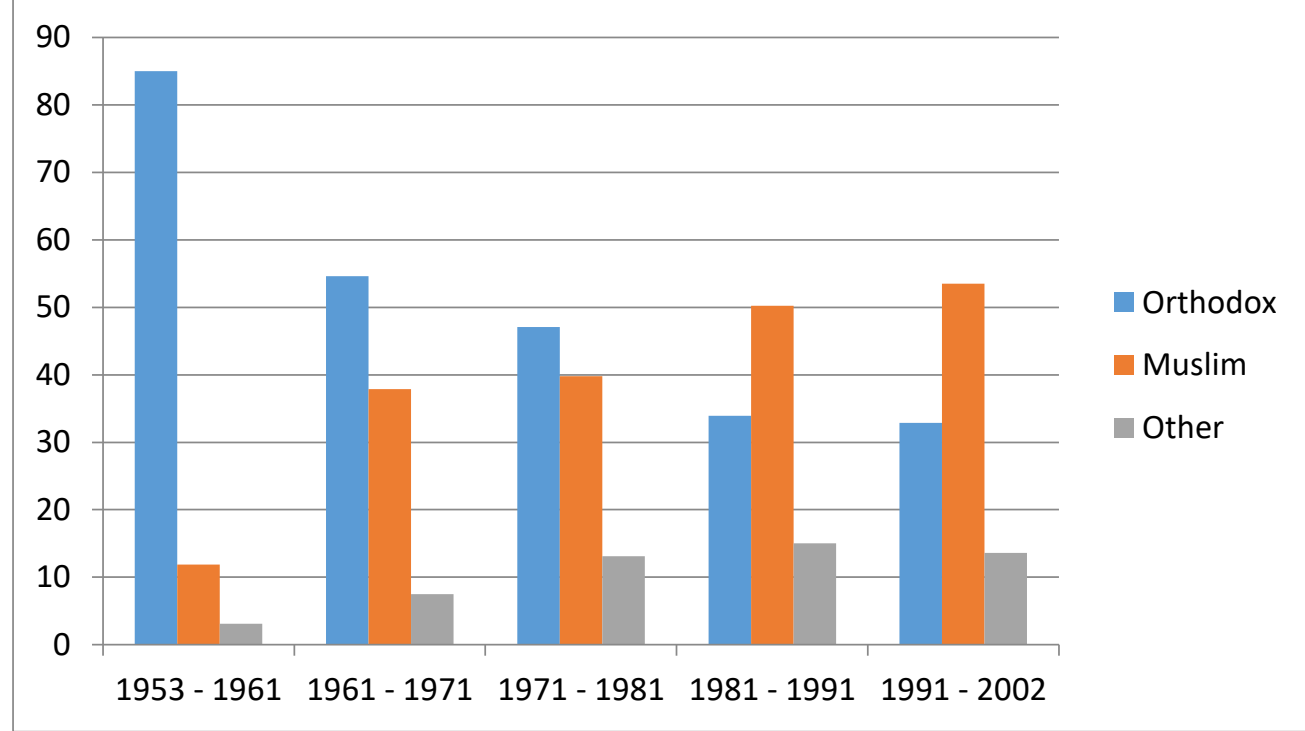

Source: Data retrieved from the State Statistical Office of the Republic of Macedonia and elaborated by the authors. 